\title{
Nathaniel Hawthorne and the Style of Moral Narration
}

\author{
Mohsen Mahmoud Rowshanzamir \\ English Department, Islamic Azad University, Mashhad Branch, Iran \\ E-mail: Roshanzamir_mohsen@yahoo.com
}

Received: February 8, 2012

Accepted: February 27, 2012

Published: June 1, 2012

doi:10.5539/ells.v2n2p76

URL: http://dx.doi.org/10.5539/ells.v2n2p76

\begin{abstract}
A turning point in American literature appeared with the emergence of Nathaniel Hawthorne's narrative method as a literary phenomenon. American Revolution brought a freedom from Puritan social and religious traditions. Later, American Romanticism, through praising the individuality of the writer, doubled the distance. Hawthorne tried to reflect those social, economical, and political changes he observed during his life span in his works. Interestingly, his stories were good reflections of these religious and political changing concepts. In order to show their structural defects, he attempted to break away from the past dogmatic religious traditions. The method of narration he employed limited the range of meaning and had no reference to the reasons of events. What was in his mind was a different look at the world surrounding him. This article tries to introduce Hawthorne as a writer aware of his contemporary art. Some different parts of his stories will be mentioned which give way to this emphasis that Hawthorne had no objection to different interpretation of his texts; which is symbolically a demonstration of his attempt to get rid of the limits of his society.
\end{abstract}

Keywords: American literature, Hawthorne, Individuality, Self awareness, Symbolism, Morality

\section{Introduction}

In order to find a general literary about Hawthorne's story telling art and tradition, some of his short stories along with his famous novels "The House of Seven Gables" and "The Scarlet letter" will come to closer scrutiny. This article, also, focuses on the fact that Hawthorne's storytelling method can reverse the authorship tendency, and how it covers all traditions of narration, through emphasis on writing skill. Hawthorne's attempt to use idealistic and pragmatic styles which were inherent in his literature and culture and how they were used by him are tried to get illuminated as well.

\section{Narrative Traditions Legacy}

To American literature, Hawthorne was a writer who caused an important turning point in narration. The romance fiction he produced represented his own beliefs. Hawthorne, through skilful use of allegory and symbolism, conveyed modern themes of psychology, human nature, and social morality something which were new to his contemporaries. Hawthorne wrote in a time period in which printing technology was not yet advanced enough to equip books with pictures. Therefore, since his audience had no other means to see the setting of his tales, he frequently provided them with lengthy visual descriptions (Magill, 1991). Another component of Hawthorne's literary style was a lack of characters confrontation. Hawthorne frequently tried to present inner challenges or his stories revolved around a central themes of sin, morality, and human nature rather than heated controversies among characters (Gale, 1996).To him the exploration of human psychology through the discovery of human unconsciousness was of prime importance (Magill,1991). His presentation of 'a profound comment on the breakdown of human relationships in the society of the seventeenth century' in "The Scarlet letter" is a good example in that regard (Harris, 1985: 27) He also tries, in a very artistic way, to show the effect of individualistic sin on the society. In 'Young Goodman Brown', Hawthorne's attempts revolve around the theme of human natural wickedness when the main character had great difficulty deciding at temptation dilemma (Magill, 1991).

Two features which can be easily seen in Hawthorne's works are description and dialogue, which became characteristic features of his writing style. The use of formal dialogue was a legacy handed down to Hawthorne from the British Sir Walter Scott, who was famous in the United States and Great Britain (Magill, 1991). Hawthorne used dialogue, as a contemporary literary device, to describe human emotion (Gale, 1996). What Hawthorne did was dealing with modern themes; he expressed his ideas regarding the nature of humanity, religion, and morality and its effect on human life. In addition, he used symbolism to express ideas and themes too radical to be explicitly expressed in nineteenth century America. Moreover, through putting characters in unusual situations, he gained specific form of 
allegory. For him talking about such themes like adultery, sins, and human morality became possible through the use of specific allegories and symbols. Generally speaking, through letting his characters play lively in his tales and gaining experiences, Hawthorne carefully investigated every corner of human nature and came to conclusions based on the experiences the characters got in his tales.

In his stories, Hawthorne used many of the Puritan principles, traditions, and culture; and it seems that through this plentiful use of Puritan tenets, he proposed many basic questions regarding their religious ideals, human life and nature. On one hand, it seemed that Hawthorne had not accepted or even rejected Puritan ideas through critical illustration of their practices in his tales; and on the other, much more meticulous look at his works suggests that, he shared the same mental problems with his predecessors regarding Puritan ideals and beliefs. In his stories, he took an omnipresent look at the events; this made him more likely to take a source-of-all- knowledge part to play in his stories (pryse, 1989).

\section{Discussion}

The history of his country was of especial importance for Hawthorne. In the stories he wrote about the colonial period, he appeared as a prominent figure in the process of development and prosperity of American literature. He conveyed many of his idealistic concerns, like ethics and morality in the society. His use of nature, color, nativity and illustration of strange and wonderful concepts as sources for inspiration were among the main symbols of Nineteenth century American literature.

Edgar Allen Poe (1846), his contemporary writer, in "The philosophy of Composition" believes that story telling is the best way through which a writer can show his genius. In a criticism on Hawthorne and his works, he applied his theory of art on Hawthorne's short stories. He found points which fitted his definition of poetry. Poe claimed that the best way to express genius and talent for a poet is the rhymed poetry because it has specific length and leads to unity of effect. Such a poem can be read without pause and making it too long or short removes its effect (Mathews, 1914). The conclusion Poe reached was that Hawthorne's stories best fitted such a definition. The Unity of Effect in Hawthorne's narratives impresses human spirit severely and gratifies poetic sensations. Poe stresses on a "unique effect" to which, each word, sentence, and definition had been designed. For him, a search for truth is aim for each story (Mathews, 1914). Some of Hawthorne's stories are very good examples of reason and sensibility; which he uses to reach a desired effect. He recognizes innovation, imagination, and originality as Hawthorne's main characteristics. Poe also believes that he has originality in all aspects (Mathews, 1914).

Poe (1842) mentions "The Hollow of the Three Hills" as an example of Hawthorne's specific talent in increasing effect through using hearing sense - through which imagination is transferred and perceived- instead of vision. Poe, also, observes some traces of mysticism in most Hawthorne's stories. Hawthorne, by putting beauty and death beside each other, tries to place mystic feelings beside the mysteries of life and world to increase the effect of his story (Poe, 1842). Hawthorne chooses consciously the elements to be illustrated, and he is more concerned with the creation of an effect than to reach a fine ending in his stories. All the elements in his stories have been made fit together to produce a total unique effect. However, Hawthorne's moral principles remain hidden. He reverses the contradictions and questions the priority of one over another; but he does not necessarily change the hierarchy. According to Pryse (1989) his method of storytelling is the simultaneous questioning of nature and idealistic, pragmatic and individualistic trends of escaping and engaging with the self. He tries to show the dilemma, man faces in the natural course of life; but he leaves his character to choose his own way.

Through illustrating opposite elements beside each other in a tangible way, Hawthorne tries to increase the effect of his stories on the audience: Rappaccini's garden in "Rappaccini's daughter", Owens's butterfly in "The artist if the beautiful", and the potion in "The Birth-Mark" are all examples of this visualization process. He wants his reader to see the moral of his story himself. Similarly, David Ramsey (2006) in his article, "Narrative Strategies in The Marble Faun", believes that Hawthorne's double look - a dilemma between clear look and a tragic look- come together in a visualized and noticeable picture. That is the unity which is in fact symbolic, to some degree allegorical, lively and independent.

What Ramsey (2006) found was a specific type of unity in Hawthorne's works. Inspired by Samuel Taylor Coleridge, Hawthorne regards art as a means, not an end; a type of idealism which changes reality into a universal fact. This is what transforms multi dimensionality into unity and oneness.

Hawthorne's storytelling technique has a look at the formation of the story as a process rather than the end result or as a product. According to Bennett and Boyle (1995) each story has always something about itself to tell; in other words, stories convey many aspects beyond the main trend of the narration. One of these aspects is the procedural steps through which the story gets created. This is the difference between a story and lyrical poem (Bennett, 1995). This is what Hawthorne lets his characters do; he lets them choose for themselves at the critical moral dilemma. 
That is the reasons why a sense of naturalness moves along with the reader throughout the story.

Bennett and Boyle (1995) regard a story interesting when it takes the reader page by page and $\mathrm{s} / \mathrm{he}$ is looking forward to seeing what happens in the next one. Having this criterion in mind, Hawthorne's story telling techniques cannot be easily classified. He uses those techniques and contradicts them at the same time.

One of the main techniques used in storytelling is Deviation. It increases the final effect of the story and leads the story to an end at which all disputes get resolved and the reader feels $\mathrm{s} / \mathrm{he}$ has grasped the moral of his story. Hawthorne feels free in the conscious abundant use of this technique in the process of narration. This makes his readers see what he has in mind. For example in "Alice Doane's Appeal":

"As they went, they seemed to see the wizard gliding by their sides, or walking dimly on the path before them. But here I paused, and gazed into the faces of my two fair auditors, to judge whether, even on the hill where so many had been brought to death by wilder tales than this, I might venture to proceed. Their bright eyes were fixed on me; their lips apart. I took courage, and led the fated pair to a new-made grave, where for a few moments, in the bright and silent midnight, they stood alone. But suddenly there was a multitude of people among the graves" (Hawthorne, 1995).

Balance is another technique which Hawthorne uses. The general trend in Hawthorne's stories moves towards disorder from a state of equilibrium and finds the balance at last; where the reader's thirst to know is gratified. Just like the previous technique, Hawthorne uses this and contradicts it at the same time. Like many other writers of short stories, he starts his short stories disturbing the existing order and balance. His difference from other writers lies in the approach he takes to satisfy his readers' thirst to know.

He evades answering questions directly through taking an ironic approach to the realities. Stories usually answer the questions they had proposed at the beginning, like Owen's tendency to make something which is like his belief in "The artist of the beautiful", Alice's relationship with the stranger in "Alice Doane's Appeal, the role of the Rappaccini's garden in "Rappaccini's Daughter", the role Faith plays in "Young Goodman Brown" etc. Hawthorne in each story, in a contradictory fashion, provides the reader both an answer and leaves him answerless; but this is not the answer the reader has read the story for. It can be said that in this way, Hawthorne creates an illusionary sense of ending, not a real one. He leaves the end to the reader and his interpretation. In fact Hawthorne puts his reader in a situation in which he must decide the moral point based on his sense of conscience.

In "The artist of the beautiful", Owen finishes making the mechanic butterfly which he had been busy with from the beginning of the story, but unfortunately his childhood time beloved' child crushes it. Now that Owen had realized the reality of the beauty, it was not important for him to see the result of all his life long troubles gone with the wind, because that butterfly was only an illustration and a shallow face of the reality he had known. Nevertheless, the narrator never reveals his secret for us and the story comes to an end while our belief in the beauty and superficiality of the butterfly on one hand and the reality opened to Own on the other remains floating:

'He had caught a far other butterfly than this. When the artist rose high enough to achieve the beautiful, the symbol by which he made it perceptible to mortal senses became of little value in his eyes while his spirit possessed itself in the enjoyment of the reality" (Hawthorne, 1844: 25).

At the end of "Alice Doane's Appeal" the narrator reveals Alice's innocence, but the past and continuous heavy burden is still on the readers' shoulders:

"And here, in dark, funereal stone, should rise another monument, sadly commemorative of the errors of an earlier race, and not to be cast down, while the human heart has one infirmity that may result in crime" (Hawthorne, 1835).

In "Rappaccini's Daughter", Baetrice dies because of the rancor between Rappaccini and his competitor; but the reader still deals with the unresolved puzzle regarding the fact lying beneath the garden, Pappaccini's true intent, and the role of Bratrice.

According to Royal (2002), one characteristic which makes Hawthorne's narrative method specific is the conscious presence of omniscience writer, who even when the narrator plays first person, appears to be the third. Hawthorne appears to see the events in his stories through the eyes of allegorical witnesses who see everything from outside and distance. This presence confuses readers' interpretation because this omnipresent writer presents his own different interpretation. Then, the reader has to find a link between what $\mathrm{s} / \mathrm{he}$ has found out and what the narrator is trying to suggest. This narrator sometimes places himself between the writer and the reader; and he does not intend to give priority to the reader or in any way confuse their positions. Hawthorne keeps his authorship powerfully, but what distinguishes him from other writers is that he does not relate his stories to a single one narrator. He keeps his sovereignty over the story but his authorship personality is double or even multi dimensional. Contrary to his 
predecessors like Franklin and Jefferson, Hawthorne does not want to unify this multidimensional self narrator. At the beginning, he makes us believe that he is trying to confuse these two positions, but finally, he brings the story to an end skillfully with power and control.

As usual Hawthorne narrates his stories through an allegorical author who apparently watches the events from out and distances (Royal, 2002). Like Poe, Hawthorne thinks it necessary that the writer should show off in the face of his readers, and only to the degree that he does not violate their rights, he can write autobiographically.

Royal (2002) believes Hawthorne establishes his omniscience authorship in his stories in the guise of the narrator, but he directs his readers to different meanings and moral interpretations. This is why he uses the technique of definition instead of performance. If he had omitted his authorship interference in his stories, his readers then would have believed their freedom to choose different meaning structures more easily. His readers have to take a predetermined way, a route which had been drawn and paved beforehand. Through consciously determining text, controlling the elements, and the course of story, Hawthorne appears quite close to the main trend of American literature. A characteristic in the narrative style which Hawthorne has in common with Poe is the continuous illustration of the artificiality of the narrative to the reader; but unlike Poe, he does not create a unique self in which all the aspects come into a unity. This is called Hawthorne's ambiguous feeling toward his works. One characteristic of Hawthorne's narrative style is that he writes his stories with an omnipresent authorship, yet he has the tendency to leave on his readers the burden of interpretation. One of the most important themes through which Hawthorne expressed his moral concerns in the society is sin. In many of his fictions and tales, he puts his characters in moral dilemmas in which, s/he has to make a moral decision which leads him to good or evil. Yet, the interpretation is left for the reader. A very good example in this regard is his masterpiece "The Scarlet Letter" which revolves around the central theme of moral dilemma. One of these dilemmas is the central idea which is arranged in the author's mind. Here, Hawthorne enters into the realm of human psychology. Possibly, he tries to specify that the only tranquility for the human soul is to appear exactly what it is. The hypocrisy prevents the human soul to stand in its own position (Crowley, 2002). This is exhibited in the contrasted characters of Dimmesdale and Hester. Hawthorne does not make it clear what type of mistake - related to logic or emotion, atmosphere or inner soul factors- leads to her inability to the full realization of the Christian ideal of repentance.

In his important work, Hawthorne also illustrates the downward moving tendency of sin. Once man's soul separates the right path, whether because of ignorance, social situational force, or error of judgment, with every step, it is farther away and in greater difficulty. In this spiral of guilt and misery, Hester's marriage with Chilingworth was a critical error leading to other moral falls which added to her wretchedness (Person, 2007). This is what Hawthorne wants his readers to come to.

One more moral issue Hawthorne illustrates in "The Scarlet Letter" is the idea that an experience of sin causes the soul to reach noble results, through repentance. Dimmesdale's preaching is moral and influential (Wright Bird, 2007). He could not have left such a big impact on the community, had he lived and died otherwise, and Hester's downward movement led to higher elevation. Hawthorne narrates the story of a repentant heart which has paves its way toward salvation.

A repentant person who has turned away from sin becomes more sociable and has better understanding of others. This could be seen in the sermons Dimmesdale was preaching which can be indicative of his superb insight into the nature of human soul (Turner, 1961). Hawthorne is of this opinion that sin separates man from the society and alienates him. Possibly his guilt made him more understanding of others and more tolerant of other sinners. Hester is another example of this moral understanding which Hawthorne tries to illustrate. According to Turner (1961) her sin taught her to come along with others and look more warmly and sympathetically into the hearts of sinners. This is the characteristics which changed her from a rejected sinner to an accepted angel. Hawthorne used his ability through which he depicted the moral philosophy in which he believed by his style of narration. What he showed was sin with all its terrible results, yet he illustrates the other aspects of the fact, and draws our attention to have our own interpretation. Hester is a sinner; but she accepts it, openly displays it to the community, and as a result, what once was the symbol of her shame became her honor. This acceptance and lack of hiding her secret sin was the reason for her moral improvement (Person, 2007). Hawthorne's moral style of narration focuses on the significance of truth, in other words, her salvation lies in the truth. In her conversation with Dimmesdale she says:

"In all things else, I have striven to be true! Truth was the one virtue which I might have held fast, and did not hold through all extremity. . . . A lie is never good, even though death threaten on the other side!" (Hawthorne, 1990: 291).

The main theme in "The Scarlet Letter" as Hawthorne presents is sin and its social effect on the sinner and the community; thus, he presents a distinction between individualistic and social moral concerns and the effect of one 
on the other. He depicted sin and guilt as realities in human societies; to him, his ancestors' belief in Man's depravity and inherited guilt were also subjects he could illustrate through his narrative style:

"The guilt that Hawthorne felt over the actions of his ancestor had an enormous impact on his writings. In the "Custom House," his introduction to The Scarlet Letter, Hawthorne accepts the guilt from his forefathers and offers to repent for their crimes. This unusual way of viewing guilt and sin is one driving factor in Hawthorne's writing. The other, which is closely related to the first, is the relationship between men, and of man to humanity as a whole. It centers on the consequences of breaking the basic links between humans by committing acts of sin." (Bourn, 2001: 205).

Nathaniel Hawthorne in "The Scarlet Letter" focuses on the issues relating to human nature including, sin, guilt, hypocrisy, revenge and pride. According to the Biblical teaching, human beings, as children of Adam, have all inherited sin. Bible also states that human being is aware of the good and evil and he according to God's will should be free moral creatures in whom faith, love, and will power to do either good or evil can run deep (Dibble, 1988).

In the preface to "The House of Seven Gables", which Hawthorne calls a romance, he writes:

"When a writer calls his work a Romance, it needs hardly be observed that he wishes to claim a certain latitude, both as to its fashion and material, which he would not have felt himself entitled to assume had he professed to be writing a Novel" (Hawthorne, 1963:1). He also proposes his moral lesson in this way:

"Not to be deficient in this particular, the author has provided himself with a moral,- the truth, namely, that the wrong-doing of one generation lives into the successive ones, and, divesting itself of every temporary advantage, becomes a pure and uncontrollable mischief ...." (Hawthorne, 1963: 1).

Moreover, he points out that by the moral lesson the does not mean the writer should from time to time submerge his story in the pool of moralistic orders or pierce it with the moralistic spear. Hawthorne is very careful not to hang his story from each specific moralistic peg:

"The author has considered it hardly worth his while, therefore, relentlessly to impale the story with its moral as with an iron rod, - or, rather, as by sticking a pin through a butterfly, -thus at once depriving it of life, and causing it to stiffen in an ungainly and unnatural attitude." 25 (Hawthorne, 1963: 2)

Emphasizing on the idea that novel belongs to the literary genre of romance, Hawthorne evades from the real aspects of the novel and the imaginary narrative mode of fairy tales. For him, the visualization of his characters' mental states, especially at the critical points of moral decision making, is more important than dealing with their development and flourishing in the social environment.

Phoebe, a young lively girl is exactly the opposite point to the old and dejected Pyncheon couple with their façade as a symbol of their mental states. Phoebe is presented as the symbol of happiness. She is the one who brings liveliness to that sad environment. Hawthorne points out the danger threatening this young girl as the result of long company with the old sick couple:

'A flower, for instance, as Phoebe herself observed, always began to droop sooner in Clifford's hand, or Hepzibah's, than in her own; and by the same law, converting her whole daily life into a flower fragrance for these two sickly spirits, the blooming girl must inevitably droop and fade much sooner than if worn on a younger and happier breast' (Hawthorne, 1963: 134).

Phoebe is different from the other residents of the house, but because of long residence in that faded dejected environment, she is subject to the danger of such rotten values presiding this worn out house and its residents. On one hand, she should bring liveliness and happiness to this house, and on the other, she should be careful about herself not to be influenced by the existing decadence. The reader can conclude that Phoebe is playing the role of an artist who enters into everything and discovers its truth as it is the task of an artist to do so. She is, in fact, the symbol of an artist:

"Even as it was, a change grew visible; a change partly to be regretted, although whatever charm it infringed upon was repaired by another, and perhaps more precious. She was not so constantly gay, but had her moods of thought, which Clifford, on the whole, liked better than her former phase of unmingled cheerfulness; because now she understood him better and more delicately and sometimes even interpreted him to himself. Her eyes looked larger, and darker, and deeper; so deep, at some silent moments, that they seemed like Artesian wells, down, down, into the infinite. She was less girlish than when we first beheld her alighting from the omnibus; less girlish, but more a woman" (Hawthorne, 1963: 134).

Nevertheless, Hawthorne does not let us see Phoebe as a real artist. Although her passage through innocence to experience can be an advantage for her as an artist, it seems that Hawthorne does not like this vivid transformation 
which is to some degree annoying. It is not in any way possible for a person to live in such a decayed environment without being impressed by it even a bit.

The narrator passes Phoebe through the artist and reaches to Holgrave:

"But what was most remarkable, and, perhaps, showed a more than common poise in the young man, was the fact that, amid all these personal vicissitudes, he had never lost his identity" (Hawthorne, 1963: 136).

The narrator's emphasis reminds us of Eliot's depersonalization theory which expresses that although an artist should be infatuated by his art, he should keep his personal self aloof of his readers. Holgrave has a curious personality and from time to time confuses Phoebe with the questions he asks about Clifford:

"How disturbed?" inquired Holgrave. "By things without, or by Thoughts within?" (Hawthorne, 1963: 137).

But this unique symbol of art which has been related with his surrounding world but not yet influenced by it will not last long and Hawthorne tries to reveal his weakness.

As we are inclined to suppose, based on the existing reasons, that Holgrave is the real artist, Hawthorne breaks our supposition and shows him as one of those young people whom we meet in our daily lives.

Despite the ironical atmosphere seen in this chapter, Hawthorne again, through what Phoebe expresses, reveals his inner intentions regarding the vanity of social structures and criticizes them. It seems that the concept of art that he holds in mind includes change and difference. He rejects the blind acceptance of those social structures, but his emphasis is on the analysis of those patterns and delving into the depth of social moral concepts:

"Whatever we seek to do, of our own free motion, a dead man's icy hand obstructs us! Turn our eyes to what point we may, a dead man's white, immitigable face encounters them, and freezes our very heart! And we must be dead ourselves before we can begin to have our proper influence on our own world, which will then be no longer our world, but the world of another generation, with which we shall have no shadow of a right to interfere. I ought to have said, too, that we live in dead men's houses; as, for instance, in this of the Seven Gables!" (Hawthorne, 1963: 141)

The narrator, in this chapter, describes the different characters in a preplanned fashion. He begins with the old, sterile Clifford, and then jumps to happy, lively, and young Phoebe on the opposite point. After focusing on Phoebe's strong points and emphasizing on the positives aspects of her personality, reveals her weak points which is her acceptance and internalization of the change for which we have to be sorry. Because of this idea, Hawthorne introduces another character who has not been impressed by his environment into the narrative: Holgrave.

The fifteenth chapter begins with the narrator's engagement with the contrast between judge Pyncheon's real personality and his social character:

"The Judge, beyond all questions, was a man of eminent respectability. The church acknowledged it; the state acknowledged it. It was denied by nobody. In all the very extensive sphere of those who knew him, whether in his public or private capacities, there was not an individual-except Hepzibah, and some lawless mystic, like the daguerreotypist, and, possibly, a few political opponents" (Hawthorne, 1995: 178).

The narrator expressively is aware of his role as a storyteller of a series of events in which distinguishing truth from falsehood is wrong. He no longer shows interest in how much characters can be the symbol of real artists - as in the case of Holgrave - his concern is now over the difference between reality and imagination: the difference between apparently calm personality of the judge in the eyes of the people from the Satan within his self.

Hawthorne interrupts the main trend of the story with the dead body lying on the foot of the wall of the aristocratic palace. Nobody would recognize the body but:

"Now and then, perchance, comes in a seer, before whose sadly gifted eye the whole structure melts into thin air, leaving only the hidden nook, the bolted closet, with the cobwebs festooned over its forgotten door, or the deadly hole under the pavement, and the decaying corpse within" (Hawthorne, 1963: 179).

The importance of this part of the passage about the role of the artist can be related to the issues which were mentioned about the real nature of Clifford, Phoebe, and Holgreve. All seem non Fallible and error free, and this is what common people see in their lives and never hesitates about it. This is what only a real artist is bound to do; to penetrate into the depth of matters and reveal the reality which is not always a simple task to perform. Pyncheon in the eyes of people who know and respect him - except for Hepzibah who has a look at his inner Satan- appears a real gentleman.

Hawthorne makes the best use of his position as the creator of his works. He interrupts the trend of his story continuously to make his readers familiar with his description, explanation, and interpretation of his characters, their 
positive and negative aspects of personalities to show his upper position as the writer and artist.

Hawthorne chose romance to decode the real nature of human experience. Romance leaves him free to reveal the human life experience in a real world. His works are between reality and imagination; that makes them well fits the two genres of romance and novel. This is why, Richard Chase (1974) introduces Hawthorne as simultaneously and contradictorily emotional and emotionless, lazy and lively, radical and conservative, and Gnostic and money minded.

\section{Conclusion}

Hawthorne does not reconcile all the opposite elements. He cannot illustrate the reality of his stories fully, nor can he hide it: the reality of the Rappccini's garden, Owen's secret knowledge, the minister's veil, the evil aspects of satanic side of human being, and also his own art of narration in general through which he has presented his moral concerns.

His authorship interferences intended to keep his authorship sovereignty, which in other ways it leads to its elimination. Through proposing questions, new alternatives as reasons and results of different story events, rejection of the elimination of the distances among his characters, Hawthorne opens new ways for different moral interpretations which sometimes are beyond his own knowledge. His method for evading from presenting all the fact which he uses as a tool to keep his sovereignty leads finally to opening up new horizons for interpretations which sometimes go beyond his knowledge and skill. What he did is mostly presenting humane dilemmas at which man has to decide toward morality.

The narrator's attempt to interfere in the process of the story is done intended to keep his control over the incidents of the narration, and its failure is the result of its multidimensionality - and not its unity.

Hawthorne's tendency to show he knows more than the reader- reason for his authorship interferences and interpretations - accompanies with his rejection of his sovereignty as the writer; But, at the same time some questions are proposed in regard with the philosophy of these interferences. Finally, Hawthorne's conscious presence in the structure of his narratives which is intended to establish his sovereignty as the writer reveals a lack which goes beyond his knowledge. He presents moral situations and the critical points at which man has to take decision, and then the reader is the one who has to see the consequence of the character's moral position. He is teaching us, not through direct preaching, but he lets the readers see and come to their own interpretations. He is quite well aware of his readers' capacity of understanding. He created many stories that were reflections of his life experiences as a Puritan descendant. He wrote many short stories that came to an end with a moral point which were learned through the struggles and challenges of the characters who faced many moral dilemmas where they had to choose between right and wrong.

\section{References}

Beidler, P. (1978). Franklin and Crevecoeur's Literary Americans. Early American Literature, 13(1), 50-62.

Bennett, A., \& Nicolas B. (1995). An Introduction to Literature, Criticism and Theory. Cornwall: Prentice Hall.

Chase, R. (1974). American Novel and its Tradition. Maryland: John Hopkins University Press.

Gale, E. (1996). Discovering Authors. Detroit: Gale Research Company.

Harris, L. (1985). Nineteenth Century Literature Criticism (Vol. 54). Detroit: Gale Research Company.

Hawthorne, N. (1835). Alice Doane's Appeal. Available at: www.2020ok.com (accessed 15 December 2011).

Hawthorne, N. (1844). The Artist of the Beautiful. Available at: www. Feedbooks.com (accessed 2 January 2012)

Hawthorne, N. (1963 [1851]). The House of Seven Gables. Ohio: Ohio State University Press.

Hawthorne, N. (1990 [1850]). The Scarlet Letter. Oxford: Oxford University Press.

Magill, F. (1991). Magill's Survey of American Literature (Vol. 13). New York: Salem Press.

Magill, F. (1991). Critical Survey of Long Fiction (Vol. 4). Pasadena, California: Salem Press.

Mathews, B. (1914). The Oxford Book of American Essays. New York: Oxford University Press.

Poe, E. A. (2008 [1842]). Hawthorne's Twice-Told Tales In Bloom's Classical Critical Views. New York: Infobase Publishing.

Poe, E. A. (1979 [1846]). The Philosophy of Composition. In The Complete Works of Edgar Allan Poe, 14, edited by James E. Harrison, pp. 193-208. New York: AMS Press.

Pryse, M. (1989). A Course Guide to Accompany the Norton Anthology of American Literature. New York: Norton 
and Company.

Royal, D. P. (2002). An Absent Presence: The Rewriting of Hawthorne's Narratology in John Updike's S. Critique. 44.1: 73-85. http://dx.doi.org/10.3366/E0309520709000077

Ramsey, S. D. (2006). Narrative Strategies in the Marble Faun Studies. Language and Culture, 27(2), 201-219. http://dx.doi.org/10.3366/E0309520709000120 